\title{
INNOVATIVE APPROACHES IN DEVELOPMENT OF EDUCATIONAL MATERIALS: A CASE STUDY OF SCIENCE TEACHERS
}

\author{
Dr. Munise SECKIN KAPUCU \\ ORCID: 0000-0002-9202-2703 \\ Faculty of Education \\ Eskisehir Osmangazi University \\ Eskisehir, TURKEY \\ Dr. Zeynep YURTSEVEN AVCI \\ ORCID: 0000-0001-7740-743X \\ Faculty of Education \\ Eskisehir Osmangazi University \\ Eskisehir, TURKEY \\ Dr. Irfan SURAL \\ ORCID: 0000-0003-2232-9483 \\ Faculty of Education \\ Eskisehir Osmangazi University \\ Eskisehir, TURKEY
}

Received: 05/11/2020 Accepted: 13/04/2021

\begin{abstract}
This study aims to examine experiences of science teachers in the training process they attended for innovative technology applications. Case study method, one of the qualitative research methods, was used for study design. 35 science teachers, who work in public schools affiliated to Ministry of National Education in seven regions of Turkey have participated in the study. In determining the participants, maximum variation and criterion sampling methods from the purposeful sampling methods were used. In the research, teachers were provided with training on innovative technology applications for a week period. Data collection tools used in the research were the reflection form developed by the researchers, daily activity evaluation forms and e-portfolios. The data was analyzed applying content analysis technique. Regarding the findings, teachers found innovative technologies positive in terms of attracting student attention, increasing involvement of the students, and facilitating/concretizing learning; and negative in terms of causing distraction and technology dependence. Regarding the results obtained from e-portfolios, participants produced concrete or digital products involving making a spacecraft, making Virtual Reality (VR)lasses, constructing hologram pyramid, creating picture holograms and video holograms. In addition, the participants emphasized that they mostly had positive opinions about the training they have attended, they encountered difficulties in Unity software, they plan to include innovative technology applications in science education especially in teaching astronomy and space concepts, they suggested stakeholders increasing the trainings given by experts and applied professional development activities.
\end{abstract}

Keywords: Science education, augmented reality, virtual reality, digital holography, innovative technologies.

\section{INTRODUCTION}

The increase in the use of technology in education and training processes has enhanced its role in education and has made the use of technological tools indispensable in learning environments as in all areas of our lives. In the digital age we live in, it is inevitable for technological tools to change and evolve. In addition to the hardware tools such as computer, projection, tablet, smart board, and software such as PowerPoint, 
educational software, animations, simulations, various settings and tools that differ in terms of both hardware and software are being used in the classroom setting.

Students have sometimes difficulties with understanding abstract visualisations even if they are presented in $3 \mathrm{D}$ space. The problem is how to decrease the gap between the real world which surrounds us and the abstract models which are used in simulations (Zagoransk \& Divjak, 2003). Since there are more abstract concepts in science, it is thought that innovative technology applications will be particularly effective in teaching subjects or concepts, as they appeal to more than one sense. In this context, this study is planned to be carried out with science teachers who have different characteristics.

We see augmented reality, virtual reality and hologram technologies, which can be called as innovative technologies, among the most popular tools and settings. As in many fields such as health, defense, communication, marketing and tourism, the applications developed with these technologies are also becoming widespread in the field of education. Regarding the applications developed in recent years, especially mobile applications, accessible innovative technology applications that teachers can use on their own are observed to highly increase. Virtual, blended and augmented reality applications offer a rich learning environment to the learner using interactive, collaborative, creative, problem-solving based learning approaches. In this respect, in a learner-centered approach virtual, blended and augmented reality applications can be used as auxiliary material in education and training (Orhan \& Karaman, 2011). Within the scope of this research, we focused on augmented reality, virtual reality and hologram technologies because of their potential for use in science education.

\section{Innovative Technologies}

In this study, Augmented Reality, Virtual Reality, and Digital Hologram technologies are considered as innovative technologies. Thus, these technologies are meant by innovative technologies in this study. We start with the literature on these technologies.

Augmented reality is defined as the technologies that enable the users to see improved or enhanced version of the world with the help of textual, audio-visual, etc. information (Gonzato, Arcila, \& Crespin, 2008). The most prominent feature of augmented reality technology is using virtual objects in the real-world setting, enriching them with virtual objects such as pre-designed images, sound, video or animation. In this way, the real-world setting is enriched with virtual objects, in other words augmented. We can see the term augmented reality as enlarged reality, enriched reality, enhanced reality or supported reality in the literature (Ozarslan, 2013). In augmented reality technology, the communication is established via augmented reality application, by receiving information from real world through sensors (Craig, 2013). Many hardware and software used by augmented reality systems are also used by other technologies. However, the distinctive feature of augmented reality is the seamless integration of virtual objects into a real context (Billinghurst, Kato, \& Poupyrev, 2001; Chang, Morreale, \& Medicherla, 2010). Use of Augmented Reality (AR) applications in education was observed to have positive effects on the learning process by facilitating the understanding of the concepts (Chen \& Tsai, 2012; Kaufmann \& Schmalstieg, 2003; Klopfer \& Squire, 2008); concretizing abstract concepts (Chang et al., 2015; Huang, Chen, \& Chou, 2016; Lin, et al., 2013; Sommerauer \& Muller, 2014; Tsai, Liu, \& Yau, 2013); attracting and increasing student's attention (Chang et al., 2014; Di-Serio, Ibanez, \& Kloos, 2013; Hsiao \& Rashvand, 2011; Ibanez, Di-Serio, Villaran-Molina, \& DelgadoFloos, 2014; Hsu, 2015; Lin et al., 2013; Wojciechowski \& Cellary, 2013; Yildirim, 2020), increasing student motivation (Di-Serio et al., 2013; Klopfer \& Squire, 2008; Yildirim, 2020), and increasing the willingness to learn (Chen \& Tsai, 2012; Wojciechowski \& Cellary, 2013).

Virtual reality (VR), on the other hand, is a simulated experience that may look like the real world or may be completely different from the real world. Technically, virtual reality is used in computer-based 3D settings where individuals experience the feeling of being there. Users get into the virtual settings through various peripherals (helmeted screens, etc.) ("Virtual reality," 2021). Since the moment he/she enters into the setting, the user is disconnected from reality and completely lives the feeling of being in the setting created by virtual reality. Virtual reality is a fully artificial digital setting that uses computer hardware and software to create the look of a real setting for the user (Kipper \& Rampolla, 2013). Yildirim, Elban and Yildirim (2018) emphasized that VR applications are effective in increasing students' interest towards the 
course by giving them the feeling of being in a setting even though they are not physically present there. In addition, there are studies reporting that VR applications will help students understand better and the acquired knowledge to be permanent by allowing physical investigation of the objects that are not actually accessible (Freina \& Ott, 2015). In this study, no classification is done in terms of reality. We handle AR, VR and Digital Hologram as innovative technologies.

Another innovative technology, digital hologram, is one of the imaging tools. It is a 3-dimensional image, created by a holographic projection from a consistent light source, such as laser (Sudeep, 2013). There are three popular types of holograms, namely reflection, transmission, and computer-generated holograms. Each hologram type has its own characteristics and its use depends regarding the object to display (Barkhaya $\&$ Halim, 2016). 3D (3-dimensional) Hologram works by creating an illusion of a 3-D image. To generate illusions, first, a light source is focused on the surface of an item and the light is scattered. Meanwhile, a second light source is used to spread the same item and thus create an image between both light sources. This results in a connection between both light sources, causing a diffraction that gives an impression similar to 3D image (Ghuloum, 2010). There are findings showing that holograms are effective in students' concrete learning and support their thinking and problem-solving skills (School \& Unver, 2016; Yamaguchi \& Yoshikawa, 2012).

Augmented reality applications include applications such as Quiver, ATF Store (augmented reality cards), MikrosAR, Anatomy 4D (Abdusselam, Kilis, Sahin Cakir, \& Abdusselam, 2018; Durak \& Yilmaz, 2019; Erbas \& Demirer, 2014), whereas virtual reality applications include applications such as SkyView, Google CardBoard, Solar System Scope, Inmind VR, Spacecraft 3D, Titans of Space (Arici \& Aktamis, 2013; Dagdalan, 2019; Tepe, Kaleci, \& Tuzun, 2016). Digital holograms, on the other hand, are not the kind of applications that can be installed on mobile devices, they are the technologies requiring the use of an apparatus such as a hologram pyramid and various computer software prior to the hologram generation.

\section{Studies on Educational Use of Innovative Technologies}

Effective integration of innovative technologies is considered essential for the success of teaching activities (Caliskan, 2017; Koyunlu Unlu \& Dokme, 2020). Augmented reality and virtual reality were observed to have an important place in innovative technology applications. According to Abdulselam (2014), laboratory settings created with augmented reality in physics instruction affect students' academic success and attitudes positively. Students generally stated that the applications performed with innovative technologies are fun, attractive and facilitate their learning (Caliskan, 2017).

The positive effects of AR technology on learning have been recognized in previous studies as the development of skills and knowledge, enriched learning experiences and improvement of cooperative learning (Wu, Lee, Chang, \& Liang, 2013). Seo, Kim, and Kim (2006) tested the effect of AR between 9-12 years old students when they were learning volcanoes. The study compared the methods involving textbooks, AR under teacher control and AR under student control. The study showed that students learned significantly better under AR conditions, but no significant difference was observed between AR groups. Chen (2006) reported that students better understand chemical structures by using AR than textbooks. In the study of Sin and Zaman (2010), students learned the characteristics of the solar system through either textbook or AR. The pre-test scores of the students who used the textbook increased by $17 \%$, while the pre-scores of the students using AR system increased by $46 \%$ and they reported higher comprehension of the concepts. However, there are significant obstacles for the successful use of augmented reality in the classroom, such as time and technical expertise regarding materials development (Kerawalla, Luckin, Seljeflot, \& Woolard, 2006).

Virtual reality is widely used at several levels. It was used in many areas in a collaborative immersive system, from nurse training (Green, Wyllie, \& Jackson, 2013), to medical virtual hospital training (Kleven, 2014), simulated pulling out decayed tooth exercises (Eve et al., 2014) for dentistry students. Research shows that virtual reality can play an important role in research activities and provides the opportunity to visualize and simulate the events that cannot be perceived in real life. In medical research, virtual reality allows not only visualization, but also the possibility of moving in neural tissue (Morehead et al., 2014). The CAVE VR system developed in another study is an application used to display magnetic fields in the solar system (Kageyama, 2013). 
Studies on the use of 3D hologram technology in education show that holograms provide benefits in many areas. In his study, Monnin (2010) emphasized that 3D hologram technology can be an effective auxiliary learning technology for attracting the attention of children because of the free floating of the laser image in the air. Many studies underline that the 360-degree hologram enables students to observe the images of an object from different angles (Aina, 2010; Robin, 2013). In a meta-analysis conducted by Barkhaya and Halim (2016), 3-dimensional hologram was found to be an effective teaching tool in attracting students' attention and improve their understanding. In addition, hologram technology has a positive impact developing creative thinking, improving problem solving skills, and strengthening cooperation and communication (Kim, Jung, \& Kim, 2018).

Augmented reality, virtual reality and digital hologram applications from innovative technologies, were thought to contribute to learn scientific concepts in a more enjoyable way, to increase students' scientific literacy level, to use mobile applications in education and to integrate the use of telephones into education. It is thought that innovative technology applications will be effective especially in the instruction of science subject or concepts, which are highly abstract, because they address more than one senses. In this context, this study is planned to be carried out with science teachers. This study is based on the project "Innovative Approaches in Science Education for Enriched Educational Material Production", which was supported by TUBITAK (The Scientific and Technological Research Council of Turkey) 4005 Innovative Education Practices Support Program. This program is for teachers and academicians. It aims at interactively developing innovative approaches, strategies, methods and techniques specific to its branches and teaching profession in general. Augmented reality applications are among the types of activities to be supported in this project type. For this type of projects, the duration of teacher trainings, the total number of event days is limited to a maximum of 10 days, including welcoming meeting and closing ceremonies. Therefore, the duration of the activities was limited to 6 days for this study due to the regulations for the project type.

\section{The Aim of the Study and Research Questions}

This study aims to examine the experiences of science teachers in the training process they attended on innovative technology applications. For this purpose, the following questions were addressed:

1. What are the opinions of science teachers regarding the positive and negative aspects of using innovative technology (augmented reality, virtual reality, digital hologram) applications in science education?

2. What are the experiences and skills acquired by science teachers during the activities?

3. What are the thoughts, suggestions and future plans of science teachers about the activities they attended during the project?

\section{METHOD}

\section{Research Design}

This study was designed as a qualitative case study. Case studies aim to investigate a particular case in detail, rather than being an experimental research, where the answer of the "what can we learn from this case?" question is sought (Stake, 2008). Since case studies contain a lot of data, the data analysis process is a complex process requiring careful execution (Mills, Durepos, \& Wiebe, 2010). The difference of this type of research from other research methods is that it focuses on how and why questions and allows in-depth investigation of an event or phenomenon that cannot be controlled by the researcher (Yildirim \& Simsek, 2016).

This study was carried out as part of a project where science teachers experienced innovative technology applications for a week. According to Creswell (2007), case study is an in-depth examination of a limited system based on large and comprehensive data sets. In this study, a case study was used to examine teachers' experiences of innovative technology applications in a real environment in a one-week period.The case examined in the study consists of science teachers' experiences related to various augmented reality, virtual reality and digital hologram applications. Researchers need different types of data to develop deep understanding of the situation under study (Creswell, 2011). Therefore, the data sources of the study consist of daily activity evaluation forms, reflection forms and e-portfolios. 


\section{Participants}

35 science teachers who were working in the public schools affiliated to the Ministry of Education, located in seven different regions of Turkey, in 2018-2019 academic year have participated in the study. In qualitative research, it is seen that the selection of the study group deliberately uses diversity and include participants different characteristics for validity and reliability (Merriam, 2013). The purpose of choosing maximum diversity sampling methods were used in this study is to find common points of science teachers with different characteristics regarding their technology experiences. Diversity was targeted in terms of variables such as provinces, teaching experience, and gender in the selection of participants. Since this study aims to reveal the innovative technology experiences of science teachers, working as a science teacher in schools affiliated to the Ministry of National Education and not attending a training on innovative technology applications before were sought as the criteria for selection of the participants. The demographic information of the science teachers participating in the study is presented in Table 1.

Table 1. Demographic characteristics of science teachers

\begin{tabular}{llcc}
\hline Variables & & $N$ & $\%$ \\
\hline \multirow{2}{*}{ Gender } & Female & 18 & 51.4 \\
& Male & 17 & 48.6 \\
\hline \multirow{3}{*}{ Seniority } & $1-5$ years & 8 & 22.6 \\
& 5-10 years & 9 & 25.7 \\
& $10-15$ years & 10 & 28.6 \\
Graduated Department & $15-20$ years & 5 & 14.3 \\
& 20-34 years & 3 & 8.6 \\
\hline \multirow{3}{*}{ Region } & Science Teaching & 34 & 97.1 \\
& Physics & 1 & 2.9 \\
& Black Sea region & 5 & 14.3 \\
& Marmara region & 5 & 14.3 \\
& Aegean region & 5 & 14.3 \\
& Mediterranean region & 5 & 14.3 \\
& Central Anatolia region & 6 & 17.1 \\
& Eastern Anatolia region & 5 & 14.3
\end{tabular}

As shown in Table 1, teachers from seven different regions of Turkey's have participated in the study. In addition, diversity was sought in the provinces where the teachers worked. The 35 participants of this study were from 34 different provinces.

\section{Research Process}

In Tubitak- 4005 project, which led to the emergence of this work, project director, three experts, three graduate students (guides) and fourteen instructors took part. One of instructors was the project manager, and three of them were also participated as the project's experts. Instructors were working in nine different universities and in a science experiment center. Five of the instructors are specialists in science education, six in information technologies, one in physics and two in engineering. Two of the graduate students were from science education and one from information technologies.

A pilot study was carried out prior to the application in order to ensure a smooth research process. A one-day program was set, and a pilot application was carried out before the research activities, at the school where five science teachers were working in Eskisehir. The pre-application covered the pilot applications of the following topics: Let's Get to Know Augmented and Virtual Reality: What Can We Do?, Review of Science Education Curriculum in terms of Innovative Technology Applications, We Design Our Virtual Glasses, 
Digital Hologram Applications as Ice Breakers in Science Education. After the pilot study, the activities were evaluated with the teachers, and the content of the activities was improved, and an activity evaluation form was created. Activity evaluation form consisted of the questions including the opinions of the participants about the activities they attended that day, their contributions in terms of using innovative technologies and effects on their professional development.

In the actual application of this study, teachers were provided with one-week, 36 hours of training on innovative technology applications. Since the opening activity and meeting took place on the first day of the program, the trainings started on the second day. This training program included 18 activities. Regarding the methodology, augmented reality applications, workshops, collaborative group works, and mobile applications took place during the training sessions. Activities planned within the scope of the project were carried out in an interactive and practical way. The titles of some activities are: Let's Get to Know Augmented Reality and Virtual Reality: What Can We Do? Let's Design an Augmented Reality Application, Review of Science Education Curriculum in terms of Innovative Technology Applications, Investigation of Microscopic Creatures with MikrosAR, We Design our VR Glasses. The visual about Let's Design an Augmented Reality Application is presented below in Figure 1.

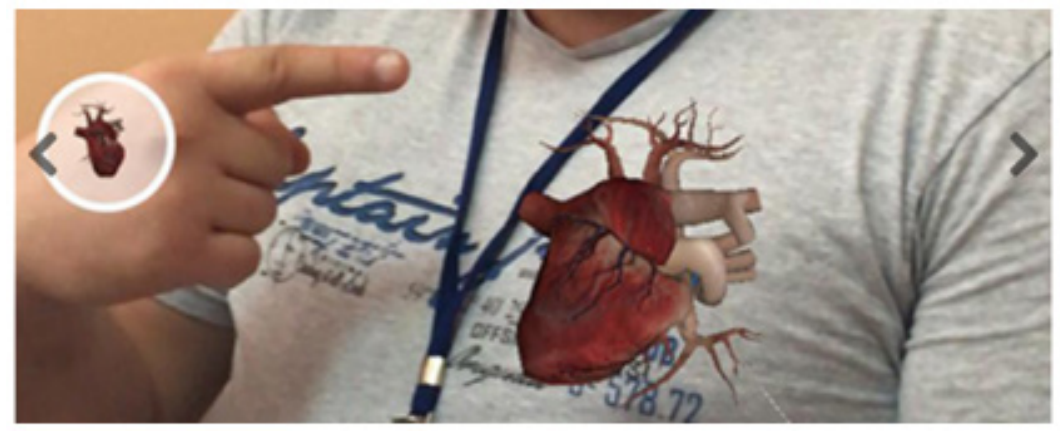

Figure 1. The visual about Let's Design an Augmented Reality Application

Research activities took place for 1.5-hour and 3-hour periods. On the first day of the training, activities introducing augmented reality and virtual reality, designing an augmented reality application, and reviewing science curriculum in terms of innovative technology applications took place; and pre-reflection forms were filled by the participants. On the second day of the training, the activities involving the examination of augmented reality in different disciplines and the applications of augmented reality in science education were carried out. The third day of the event included educational applications of virtual reality, virtual reality laboratories, applications of virtual reality in science education and making virtual glasses. On the fourth day of the training, holographic applications, hologram design, and digital hologram applications as ice breakers in science education were covered. The visual about Holographic Applications in Science Education is presented in Figure 2. On the fifth day of the event, the use of mixed reality in science education, and designing educational settings of the future with innovative technologies activities were carried out. In addition, a trip to the Eskisehir Science Experiment Center Sabanci Space House was organized and a talk on "A Journey in the Universe and Astronomy" was held.

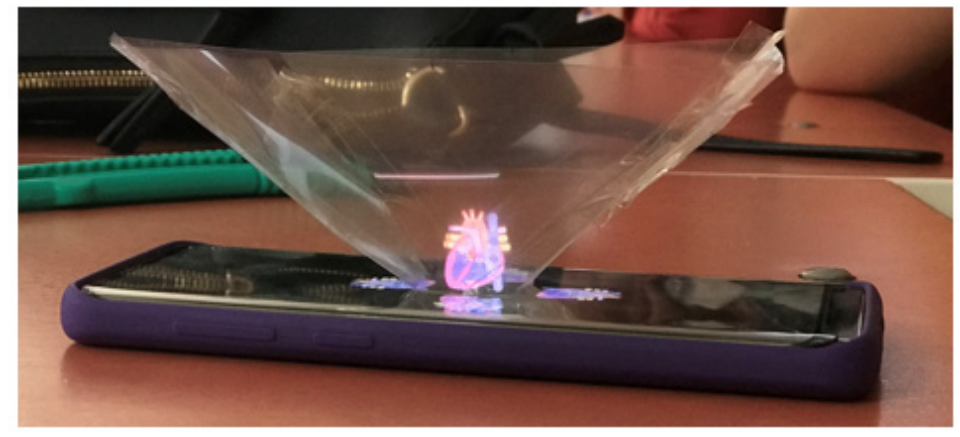

Figure 2. The visual about Holographic Applications in Science Education 


\section{Data Collection Tools}

Daily activity evaluation forms and reflection form developed by the researchers, and e-portfolios were used as data collection tools. In the development of these data collection tools, one assessment and evaluation, two science education and two information technology experts were consulted. Experts were asked to evaluate the comprehensibility of the questions in the data collection tools, the scope of the subject covered, etc. Final version of the daily activities evaluation form was formed during the pilot study. The activity evaluation form, which was originally planned to be used for each activity, was planned to be used at the end of daily activities according to the expert opinions. However, the pre and post reflection forms were initially prepared to include the same questions, the final reflection form was arranged to include innovative technology application experiences after expert opinions. The content of the e-portfolios also finalized As based on the expert opinions. The content of the product file includes 5 sections: designing an augmented reality application, designing virtual glasses, designing a hologram pyramid, mobile hologram pyramid applications, and creating a hologram video. For e-portfolios, digital products / photos / videos prepared for the event were requested to be uploaded.

The pre-reflection form applied in the first day of the training, before the activities have started, included questions about teachers' use of technology, their knowledge about innovative technologies, and questions about their experience of using these technologies in their classes. After completing the programmed activities, teachers filled daily activity evaluation form. Participants filled six activity evaluation forms in total. Daily activity evaluation form (see Appendix 1) included three questions asking the opinions of participants about the activities they attended that day, contributions of the technologies in using innovative technologies and effects of what they have learned on their professional development. The reflection form (see Appendix 2) applied at the end of the activities included eight questions regarding the opinions of the teachers about the training they attended, their plans to use these technologies in their classes, and the experiences they received from the process. In addition, teachers created a product file (e-portfolio) consisting of educational materials they developed during the activities. Regarding the content of the activities, some activities involved the development of digital content and some others the development of concrete materials. The applications were introduced by the instructor, or the topics about the use innovative technologies in the classroom were discussed. E-portfolios included digital materials and photographs taken during the activity for the ones that do not involve digital content generation. Some examples of portfolios are presented in Figure 3.
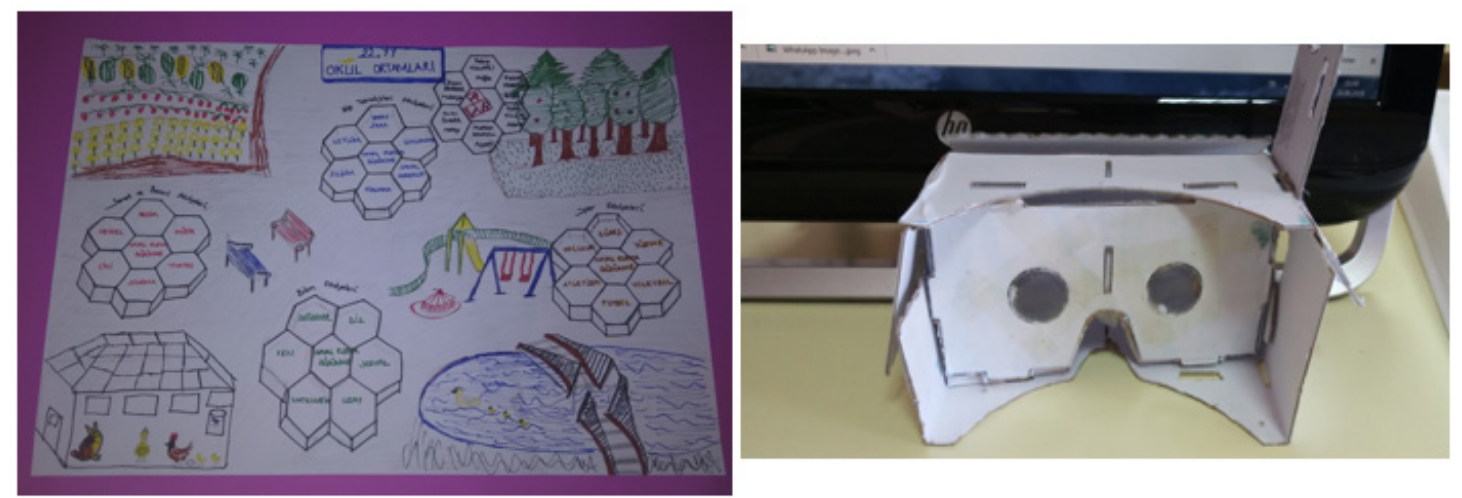

Figure 3. Pictures of Poster and Virtual Glasses from E-portfolios

\section{Data Analysis}

In the research, content analysis was used to analyze the data obtained from the pre- and post-reflection form, the daily activity evaluation form and the e-portfolios. The analysis of qualitative data include categorizing, synthesizing, and interpreting the data from different data sources is to answer the research questions (Merriam, 2009). Analyzing the raw data, coding categories were tested, and data were coded to obtain a suitable set. Themes and trends in the data have been identified. In addition, the relationships in the data were sought. The patterns between the main themes in the data were examined. Then the data was presented in an explanatory framework. During the data analysis process, data was reduced, themes and patterns were analyzed, the relations were explored and explained. Explanations were supported by quotations from the 
participants' opinions. In order to keep the identity of the participants confidential while quoting from their opinions, codes were used (For example, P1-M represents/symbolizes that the first participant was male, while P3-F represents/symbolizes that the third participant was female).

Different methods were used by researchers to ensure the validity and reliability of qualitative case studies. One of them is to use a wide variety of data sources in order to ensure internal validity and to synthesize and support each other with the triangulation method (Mills et al., 2010). In this study, triangulation method was used by collecting data via multiple data collection tools at different stages of the application. In addition, understanding an existing case through the eyes of those involved instead of repeating the measurements or experiments is important to ensure the reliability of qualitative studies (Merriam, 1995). In this context, the case examined in this study was aimed to be presented from the eyes of the participants, through their experiences with their own expressions and the products they produced. Moreover, in order to ensure the reliability of the research, all three researchers analyzed the data separately, independent of each other. Afterwards, codes produced by each researcher were compared. A consensus was reached by discussing only a few codes that do not fit (Creswell, 2013). No statistical operation was performed during the comparisons. On the other hand, in order to evaluate the external validity (generalizability) of a qualitative study, it is important to provide the reader with all the details regarding the conditions under which the study was conducted, as well as the participants and the case (Merriam, 1995). In this sense, all details about the participants and the application process were given.

\section{FINDINGS}

Findings from pre and post reflection forms, daily evaluation forms and e-portfolios are presented under three titles: the opinions about positive and negative aspects of using innovative technology applications in science education; experience and skills gained in trainings; and general thoughts, suggestions and future plans of the participants about the activities they attended during the project. Pre-training knowledge and experiences of the teachers participating in the study regarding innovative technology applications are given in Table 2 .

Table 2. Pre-training knowledge and experiences of innovative technology applications

\begin{tabular}{|c|c|c|}
\hline Category & Code & $\begin{array}{l}\text { Frequency } \\
(\mathrm{N}=35)\end{array}$ \\
\hline \multirow{4}{*}{ Innovative technology applications knowledge } & Somehow & 20 \\
\hline & Yes & 12 \\
\hline & No & 2 \\
\hline & No comment & 1 \\
\hline \multirow{4}{*}{ Knowledge of programs used in applications } & No & 12 \\
\hline & Yes & 11 \\
\hline & Somehow & 11 \\
\hline & No comment & 1 \\
\hline \multirow{8}{*}{ Innovative technology applications experiences in class } & Web 2.0 tools & 6 \\
\hline & Augmented reality & 5 \\
\hline & Mobile applications & 4 \\
\hline & 3D applications & 4 \\
\hline & Hologram making & 2 \\
\hline & Virtual glasses & 1 \\
\hline & Animation & 1 \\
\hline & No experience & 12 \\
\hline
\end{tabular}

Teachers mostly stated that they have partial knowledge about innovative technology applications, they either don't know or somehow know the programs used in innovative technology applications. As seen in Table 2, participants stated that they had experience with Web 2.0 tools, Augmented reality technologies, mobile 
and 3-D applications mostly. Four of the participants used hologram, virtual glasses, or animations in their classes. Even if only two participants reported they do not have any knowledge of innovative technologies; when they were asked about the specific application of those technologies, twelve participants reported that they 'No experience'. The statements of a teacher (P22-M) on this subject are as follows:

"Yes, I use it often. Especially I prepare digital stories with Powtoon, which is one of the Web 2.0 tools, I sometimes teach by storytelling at the beginning of the topic. I use Kahoot application at the end of learning-teaching processes to measure and evaluate what students learned, and Mentimeter application in determining pre-subject (preliminary information, readiness levels) and post-subject level of the students in the form of pre-test, post-test".

\section{Opinions about The Positive and Negative Aspects of Using Innovative Technology Applications in Science Education}

The results of the pre-reflection forms underlined increasing student interest and attracting student attention features of innovative technologies, whereas facilitating/concretizing learning are more emphasized in the statements expressed in the post-reflection form (Table 3). In addition, there is a slight increase in the number of people who think that innovative technologies are economical/practical in the post-reflection. Moreover, some opinions voiced by a small number of participants in pre-reflection, such as innovative technologies facilitate classroom control, contribute to collaborative learning, and increase creativity, are not mentioned in the post-reflection.

Table 3. Positive and negative aspects of using innovative technology applications in science education

\begin{tabular}{|c|c|c|}
\hline Positive Aspects & Pre-reflection form (\%) & Post-reflection form (\%) \\
\hline $\begin{array}{l}\text { Increasing participation/interest in the lesson- Attracting } \\
\text { attention }\end{array}$ & 37 & 32 \\
\hline Providing effective / permanent learning & 29 & 11 \\
\hline Making learning easier - Concretizing & 23 & 36 \\
\hline Fun learning & 11 & 7 \\
\hline Experiencing hard-to-reach situations & 9 & 4 \\
\hline Economic / practical / modern & 9 & 14 \\
\hline Providing diversity & 3 & 4 \\
\hline Recording learning data & 3 & - \\
\hline Facilitates classroom control & 3 & - \\
\hline Collaborative learning & 3 & - \\
\hline Increasing creativity & 3 & - \\
\hline Negative Aspects & Pre-reflection form (\%) & Post-reflection form (\%) \\
\hline Distraction & 17 & 11 \\
\hline Technology addiction & 11 & 14 \\
\hline Timely / costly & 11 & 7 \\
\hline Incorrect / unplanned use & 11 & 7 \\
\hline Decrease interaction & 11 & 4 \\
\hline Health & 6 & 7 \\
\hline Pushing students to obtain effortlessly & 6 & 4 \\
\hline Access & 3 & 21 \\
\hline Failure in controlling the class & 3 & 14 \\
\hline Insufficient teacher equipment & 3 & 7 \\
\hline Replacing the teacher & 3 & - \\
\hline Ethic & 3 & - \\
\hline
\end{tabular}


Regarding positive and negative aspects of using innovative technology applications in science education that teachers mentioned in pre- and post-reflection forms, one of the prominent titles was making learning easier by concretizing abstract concepts. A teacher (P7-F) stated in the pre-reflection form that these technologies will help teacher to guide students to reach the learning outcomes stated in the curriculum; a teacher (P13-F) in post-reflection form emphasized that these technologies will enrich the lessons; whereas one teacher (P7F) warned that these technologies should be used as auxiliary material. Even if the number of participants who mentioned this aspect slightly decreased in the post-reflections, the most reported advantage of using innovative technologies in science classes is attracting more student attention. It is interesting that while more participants were thinking these technologies supporting permanent learning in pre-reflections than post-reflections; more participants reported these technologies provide concrete examples in post-reflections than pre-reflections. It is also interesting that while a couple of participants perceived these technologies as facilitating classroom control in pre-reflections, a number of participants reported use of these technologies will make classroom control more difficult. The perception of these technologies cause distraction and/or decrease interaction tend to decrease after their experience using these technologies. On the other hand, more participants reported their concern about student access to these technologies.

The number of teachers who stated negative aspects of innovative technologies was less than those who stated positive aspects. The general trend was that these technologies can make a positive contribution to learning. However, regarding the answers given in the pre-and post-reflection forms, distracting student attention and leading to technology dependence can be named as the biggest concerns of the teachers regarding the negative aspects of innovative technologies. On the other hand, the answers given to the post-reflection form indicate that there are hesitations about students' access to these technologies. One participant (P16-M) expressed this concern as follows: "A negativity is that the technology infrastructure of the schools in some geographic regions are insufficient and it is not possible for all teachers to have a high level of interest in these issues". In addition, inability to control the class arises as another concern of teachers. A teacher who emphasized this issue (P10-F): "(Negative aspects of using innovative technology in the classroom) is time consuming, difficult to control students". Again, a teacher who described the use of innovative technologies in science education as negative in the pre-reflection form (P7-F) said "The negative feature is it can be problematic for the teacher in terms of the grasp and control of the class", whereas another teacher (P27-F) stated as "it may lead to problems such as increasing technology dependency or misuse".

\section{Experience and Skills Gained in Trainings}

Teachers created a product file (e-portfolio) consisting of materials they developed during the activities and photos taken during the activities. Participants were observed to make designs and generate products by combining their science knowledge with creative technology applications. For example, during the activity titled "Transfer of Augmented Reality Applications to Science Teaching Settings: Spacecraft 3D", the participants examined the spacecrafts previously sent to space by NASA using Spacecraft 3D, a mobile augmented reality application. Then each group designed the spacecraft they choose using given materials. In this process, each group was observed to produce creative products in group presentations and shared photos at the end of the activity.

Participants were asked to share the digital products they developed, the photos of the non-digital products they developed, the documents they obtained about the activities, and other photos and videos taken during the activities in their e-portfolios. The review of e-portfolios showed that all participants except one uploaded at least one product to their portfolios. All materials in e-portfolios were grouped under 15 codes as shown in Table 4. Table 4 shows each major themes (categories) and codes and the number of participants who installed each product. 
Table 4. Product, photo, document codes in e-portfolios

\begin{tabular}{llc}
\hline Application category & Application name & Number of participants who installed \\
\hline \multirow{3}{*}{ AG Applications } & Mikrosar & 14 \\
& Augment & 15 \\
& Spacecraft & 25 \\
\hline \multirow{3}{*}{ SG Applications } & Virtual Lab. & 2 \\
& Glasses Trial & 9 \\
& Glasses Making & 22 \\
\hline & Pyramid template & 9 \\
Hologram Applications & Pyramid usage & 18 \\
& Image hologram & 28 \\
& Audio-aided video & 23 \\
& Video hologram & 19 \\
\hline Class of the future (poster on paper) & & 11 \\
\hline Science experiment center (photos taken during the activity) & 4 \\
\hline Mixed reality (document) & & 2 \\
\hline Group activities (photos taken during the activities) & 26 \\
\hline
\end{tabular}

Participants produced concrete or digital products for spacecraft, virtual glasses, pyramid usage, picture hologram and video hologram, which are given in Table 4. Since the materials developed in Spacecraft and virtual glasses making activities are not digital, the participants uploaded the photos of these products. For pyramid usage activity, they watched hologram videos in the hologram pyramids they created during the activity and shared the photos or videos of these applications in their product files. Regarding picture hologram and video hologram applications, they shared the products they created in video format in their files. For these five main topics, 26 of the participants were observed to upload at least three out of the five products, 3 participants uploaded two products, and 5 participants uploaded only one product.

Regarding the remaining ten titles, the participants worked on digital media and materials during the activity for Mikrosar, Augment, Virtual Lab, Virtual Glasses Trial and Mixed Reality, but due to the insufficiency of time required to develop a product the photos and source documents obtained in these applications were shared in product files. Pyramid template and its effectiveness was carried out as the preliminary stage of the pyramid usage activity, whereas the audio-visuality activity was the preliminary work of the video hologram activity. Science experiment center activity was held in Eskisehir Sabanci Space House, where participants observed virtual reality shows related to various themes including space, planets, stars and earth. Four participants included the photos of this event in their product files. Regarding the "class of the future" activity, the time allocated to the activity was insufficient, therefore participants completed this activity in the time remaining from other activities and shared the photos of the posters or group works they prepared in the product files. Participants were frequently involved in group activities during the training. In the photos shared in e-portfolios, participants were observed to continue group work apart from the activities and their social interactions were high. They were observed to develop and share projects about the use of technology in science, as well as plans and project ideas for the future outside of the activity hours, during the breaks and meals. 26 participants were seen to share at least one photographs in which such group activities were carried out.

In their daily evaluations about activities, all teachers who participated in the project made positive evaluations when they were asked about the contribution of the project to their personal and professional development. As personal experiences, they thought that the training developed them in terms of preparing materials using the technologies they learned or using the technology itself, as professional experiences they thought that they could use these technologies or materials they developed in their classes. Exemplar statements of participants are given below: 
"Yes. I can now prepare my own hologram" (P4-M)

"Yes. I learned to make materials that I can use in the classroom" (P9-M).

"I had no experience, but in a week, we got a lot of information on these topics," (P24-M)

"I think I achieved a sufficient level with Camtasia about hologram production. I can also make a video hologram with CyberLink" (P13-F)

\section{Thoughts, Suggestions and Future Plans of the Participants}

General thoughts, suggestions and future plans of the participants about the activities they attended during the project were determined by examining post-reflection forms and the findings from the diaries. The general thoughts, suggestions and future plans of the participants are presented in Table 5 under the following headings: thoughts, the parts that participants have difficulty, suggestions for increasing the use of the prepared materials in science classes and possible applications in their classes.

Table 5. General thoughts, suggestions and future plans about trainings

\begin{tabular}{|c|c|c|}
\hline Category & Code & Frequency \\
\hline \multirow{4}{*}{ Thoughts } & Positive thoughts & 17 \\
\hline & Positive and negative thoughts & 6 \\
\hline & $\begin{array}{l}\text { Negative Thoughts (emphasized deficiencies/failures in } \\
\text { education) }\end{array}$ & 4 \\
\hline & No thoughts & 1 \\
\hline \multirow{5}{*}{$\begin{array}{l}\text { The parts that participants have } \\
\text { difficulty }\end{array}$} & Unity software & 12 \\
\hline & Technical issues & 6 \\
\hline & Training time & 4 \\
\hline & Programming part & 3 \\
\hline & Content generation software & 3 \\
\hline \multirow{4}{*}{$\begin{array}{l}\text { Suggestions for increasing the use } \\
\text { of the prepared materials in science } \\
\text { classes }\end{array}$} & Training\&cooperation & 11 \\
\hline & Infrastructure development & 6 \\
\hline & Increasing applications & 4 \\
\hline & Sample lesson development & 3 \\
\hline \multirow{4}{*}{ Possible applications in their classes } & Astronomy and/or space concepts & 11 \\
\hline & At the introductory stage of the lessons & 10 \\
\hline & In the concretization of abstract concepts & 5 \\
\hline & During the deepening of the subject & 4 \\
\hline
\end{tabular}

Regarding the participants' thoughts about the activities they attended within the framework of the data obtained from the post-reflection forms, they were observed to express positive thoughts about the trainings they attended. One participant (P1-M) said, "It was a very productive and enlightening training", whereas another participant (P16-M) expressed his opinion as "It was an effective, efficient training, involving both theory and practice. It was a concretized program associated with our field". The findings obtained from the diaries support these views as well. A teacher stated her opinion on this issue as, "Yes, I have learned applications like preparing a hologram video that I have not experienced before" (P10-F). Another opinion that shares this opinion is, "Yes. It was effective to live the virtual reality and see the design of virtual glasses" (P26-F).

Regarding the opinions about whether participants experienced difficulties during the training activities, they stated that they mostly had difficulties in Unity software. This is followed by technical problems, duration of the training, programming part and content generation software. One participant said, "I had 
difficulties in the applications such as Unity. We could have worked on it a little more" (P14-F). Some of the participants stated that they faced technical problems during the activities and had difficulties in dealing with them. One participant mentioned the internet problem they experienced as "WiFi connection was required to download some applications. WiFi signal could not be caught from the classroom, therefore we had to leave the class and go to the WiFi point. Since the lesson continued while we were out, we missed it" (P15-F). Another participant told about the problem he experienced with the materials "We had difficulties in performing VR glasses design activity because the cardboard was quite thick, and the material given was deficient (the utility knife was broken)" (P22-M).

As the trainings were not held in the computer lab, the participants were observed to have difficulty in following the trainings that were performed through show $\&$ do technique. One opinion that supports this is "There were times that we missed the instruction of the teacher when we were downloading the programs" (P22-M). One of the participants who emphasized the difficulty of the programs used and stated that they require programmer skills, expressed her opinion as "Some of the activities required technical knowledge, which challenged me. I had trouble in applying programs that require software or programming knowledge" (P30-F). A participant who stated that they had difficulties due to full time training and that it was difficult to gain skills in innovative technologies with this kind of training said "Yes, I believe that some programs cannot be learned in a couple of hours" (P29-M). These comments represent two results: first, some teachers do not prefer application that require higher level technology and software skills. Offering trainings on easyto-use technologies would be helpful to reach more teachers and might increase use of these technologies in the classroom. On the other hand, there is group of teachers who would love to learn about technologies that require higher level of technology skills. However, the structure and time-span for trainigns on this type of technologies should be different. More preparation should be needed to provide access to the participant teachers for particular software and they need more time for practice.

The suggestions for increasing the use of materials prepared for innovative technology applications in science classes were analyzed under the headings of educational cooperation, infrastructure development, increasing applications and sample lesson development. The opinion that the participants mentioned most in their suggestions is to increase education and training activities. One of the participants who expressed her views on collaboration with experts in the field said, "Especially information should be provided to my teacher colleagues about this" (P26-F), while another participant expressed it as "In order to increase the use of these technologies, cooperation should be done with the experts" (P33-F). Another opinion that supports them is: "It is necessary to increase the number of this type of trainings reaching more stakeholders" (P6-M). These comments indicate that teachers are willing to partipate in similar activities that brings together experts/ university and teachers together. They prefer that the number of these type of training shoul be increased. On the other hand, awareness activities should be organized to gather more teacher attention on innovative technologies.

Another issue that the participants made suggestions is about the infrastructure efforts required to use these technologies. A participant stated that "technological equipment such as tablet, VR glasses should be provided to schools" (P15-F), another participant (P30-F) stated that necessary infrastructure should be established, and all teachers should be trained. One participant who expressed his opinion about increasing practices and developing sample lessons in this field expressed his opinion as "More applications should be prepared and offered to the use of our teachers through various communication tools" (P12-M). Another participant stated that "It would be great if there were AR applications not only in space topic, but also in the topics such as systems, cells, DNA, and the structure of the atom" (P5-F). One participant (P13-F) stated that the development, implementation and evaluation of interdisciplinary sample lesson plans will make their task easier. In this sense, it can be said that there is a need inscreasing the number of applications developed using innovative technologies, especially different topics in the field of science. At the same time infrastructure should be provided in schools.

Regarding the answers given to the question "whether the participants are planning to include innovative technology applications in their classes", and if they plan, "at what stage and instructing which concepts they intend to include them", the participants mostly stated that they plan to include these applications in astronomy and/or space concepts. This was followed by the introduction part of the lesson, the concretization of abstract concepts, and the deepening of the subject. The participants emphasized that they wanted 
to include innovative technology applications especially in teaching astronomy and space concepts and underlined that they particularly chose these topics because they are quite difficult to conceptualize for students. A participant explained his opinion as "... I will use it to describe invisible concepts or space issues that are very difficult to reach" (P3-M), another participant said, "I plan to use these technologies in the topics related to space, in performing the experiments and applications that are dangerous or impossible in real-life settings..."(P19-F). We can tell that as they stated teachers would prefer using innovative technologies parcilularly for the concepts that is hard, dangerous or impossible in real life and also use of these technologies would not be limited to any part of the class time.

\section{DISCUSSIONS AND CONCLUSION}

In this research, after providing a 36-hours training to 35 science teachers on innovative technology applications, their experiences of generating educational materials in science education were examined. Regarding pre-training knowledge and experiences of the teachers participating in the study about innovative technology applications, the teachers were mostly observed to be partially informed about innovative technology applications, they either did not know or partially know the programs used in innovative technology applications. Web 2.0 tools was stated the most as the technology application tool used by teachers in their lessons. In the study conducted by Timur and Ozdemir (2018), in which teachers' opinions on using augmented reality settings in science education were examined, half of the teachers who participated in the study stated that they have used computer and smart board before, but they have not heard anything about AR applications. The findings of the research support the findings of this study.

When asked about the positive and negative aspects of using innovative technology applications in science education, teachers generally mentioned the positive aspects of innovative technologies. In the pre-reflection, increasing student interest and attracting student attention features of innovative technologies come to the forefront, whereas the statements in post-reflection emphasized facilitation/conceptualization of the learning. The findings of many studies reporting that AR, one of the innovative technologies, facilitates understanding of concepts (Abdusselam \& Karal, 2012; Kaufmann \& Schmalstieg, 2003; Klopfer \& Squire, 2008) helps to concretize abstract concepts (Chang et al., 2015; Huang et al., 2016; Lin et al., 2013; Sommerauer \& Muller, 2014; Tsai et al., 2013); and attracts students' attention and interest to the lesson (Di-Serio et al., 2013; Farias, Dantas, \& Burlamaqui, 2011; Rizov \& Rizova, 2015) support the findings of this research. On the other hand, a study concluded that using virtual reality technologies in the class increases students' interest and motivation towards the lesson (Ling \& Rui, 2016; Yildirim et al., 2018; Yildirim, Sahin-Topalcengiz, Arikan, \& Timur, 2020); as well as the meta-analysis study conducted by Barkhaya and Halim (2016), reported that 3-dimensional holograms are an effective teaching tool to attract students' attention and improve their understanding. The reason of this is the fact that 3-dimensional holograms can improve students' understanding by splitting a complex topic into a simpler form. However, according to the answers given by the teachers in the pre and post-reflection forms, distraction and causing technology dependence were mostly stated as the negative aspects of innovative technologies. The study of Dunleavy, Dede and Mitchell, (2009) reported that teachers and students find AR simulation interactive and interesting, while on the other hand, it brings unique technological, managerial and cognitive challenges to teaching and learning. This finding supports the findings of the research in terms of revealing the negative aspects of technology.

Product files (e-portfolio) consisting of enriched materials developed by teachers during the activities and photographs taken during the event were examined in order to reveal the experience and skills gained by the teachers who participated in the study. All participants except one were observed to upload at least one product to their portfolios. Participants produced concrete or digital products for spacecraft, virtual glasses, pyramid usage, picture hologram and video hologram. For these five main topics, 26 of the participants were observed to upload at least three out of the five products, 3 participants uploaded two products, and 5 participants uploaded only one product. When asked about the contribution of these activities to their personal and professional development, all teachers evaluated positively. In terms of personal experiences, they thought that preparing/using the technologies they learned developed them, whereas in terms of professional experiences they thought that they could use these technologies as materials in their classes. Participants 
stated that they gained the most skill in preparing holograms. The findings of the study that Ghuloum (2010) evaluated the effectiveness of 3-dimensional holograms as an educational tool, approximately half of the participants emphasized that 3-dimensional holograms are effective teaching tools; Yamaguchi and Yoshikawa (2012) revealed that holograms are effective in students' concrete learning. In their study aimed at supporting the thinking and problem-solving skills of pre-service teachers through holograms, Okulu and Unver (2016) observed that pre-service teachers' knowledge about astronomy increased with the products created by them in the field of astronomy. In this context, these findings highlight the importance of teachers' ability to prepare holograms, as well as the use these technologies in their classes for maximizing students' learning and supporting their own professional development. At the same time, making virtual glasses, using VR applications and using a ready-made AR application were mentioned as the skills gained by the participants. VR applications have a high potential in terms of increasing the motivation of learning and contributing to the comprehension of the content by giving the users a sense of being in a setting that is not there in reality, allowing interaction and increasing user participation (Ott \& Tavella, 2009; Freina \& Ott, 2015). In the experimental studies reviewed by Ozdemir (2017), helping to increase attention, helping to understand the subject and increasing the willingness to learn were at the top of the reported benefits of using AR. These studies highlight the importance of teachers' ability to use VR and AR applications.

Participants were observed to mostly have positive thoughts about the training they have participated in. They mostly stated that they had difficulty in Unity software. Participants emphasized that they plan to use innovative technology applications in especially in teaching difficult subjects such as astronomy and space concepts. Virtual reality programs were reported to be useful in the studies on teaching astronomy concepts (Barron \& Orwig, 1997; Chen, Yang, Shen, \& Jeng, 2007; Diakidoy \& Kendeou, 2001; Trundle $\&$ Bell, 2010). In the study examining the educational augmented reality applications carried out by Arslan and Elibol (2015), it was found that there are educational applications in the subjects of Fossils, Dinosaurs and Animal Training, Science and Technology Education, Solar System and Space Education. In the study of Arici (2013) using virtual reality programs in the "Solar system and beyond: Space puzzle" unit, he concluded that 3-dimensional visual materials presented by virtual reality programs affected the achievement of 7 th grade students in science and technology course. These findings support the findings of the research. In another study by Abdusselam (2014), teachers stated that augmented reality settings may provide benefits in visualizing and concretizing the magnetic field for teaching physics, especially magnetism. On the other hand, students stated that augmented reality setting helps them to understand and comprehend the events better, this setting offers a more realistic environment in applications, shapes the visuality, concretizes the concepts. Regarding their suggestions to increase the use of materials prepared for innovative technology applications in science lessons, participants mostly suggested to increase the trainings and applied professional development activities given by experts.

In summary, the review of the results shows that the teachers find innovative technologies positive in terms of increasing student interest, attracting student attention, and facilitating learning/concretization; whereas potential negativities such as distracting students` attentions and causing technology dependency. Science teachers stated that the project helped their personal development in the sense of preparing/using the technologies they learned and that they may use these technologies as course materials in their classes. In addition, the participants stated that they gained the most skill in preparing holograms. Additionally, they suggested the number of trainings given by experts and applied professional development activities should be increased.

\section{Limitation and Recommendations}

In this study, 35 science teachers were given 36-hour training on innovative technology applications and their experiences of producing enriched materials in science education were examined. The number of participants and duration of the activities were determined according to the possibilities of type of the project. This situation constitutes the limitation of the study.

In order to increase the number of teachers who can develop enriched materials through augmented reality, virtual reality, hologram technologies, applied teacher trainings focusing on the widespread and effective use of current mobile applications for innovative technology applications in education can be expanded. 
The participants of the study suggested that these trainings should focus on a single technology and include certain predetermined programs in more detailed way. On the other hand, new studies can be designed with different methods, data collection tools and various study groups in order to investigate the use of innovative technologies in the classes, the difficulties experienced in the real classroom setting and potential solutions after the completion of the trainings. Studies can be conducted in which innovative technologies are used in different units in the science course and its results are examined in terms of various variables (success, motivation, attitude, 21 st century skills, interest in STEM areas, etc.).

Authors' Note: This study is a part of the project that was supported by the Scientific and Technological Research Council of Turkey, Project TUBITAK: 218B571.

\section{BIODATA and CONTACT ADDRESSES of AUTHORS}

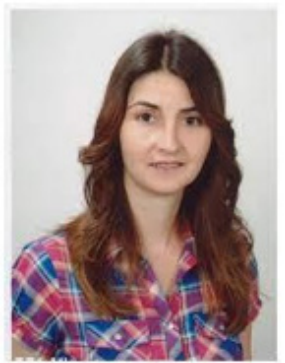

Dr. Munise SECKIN KAPUCU, Associate Professor, has been working as a faculty member in the Department of Science Education at the Eskisehir Osmangazi University, Faculty of Education, at the Department of Mathematics and Science Education, Turkey. Dr. Seckin-Kapucu has studies on science and technology program, teaching the nature of science, and the use of different technologies in science courses.

\section{Munise SECKIN KAPUCU}

Eskisehir Osmangazi University, Faculty of Education, Address: Eskisehir Osmangazi University, 26040, Eskisehir, Turkey

Phone: +90 222 2393750/1662

E-mail: muniseseckin@hotmail.com

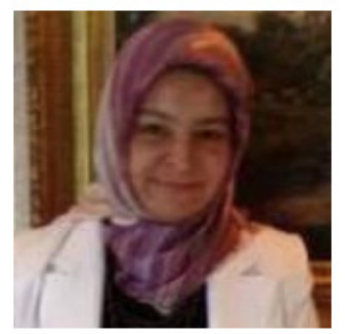

Dr. Zeynep YURTSEVEN AVCI, received her Ph.D. degree in 2012 from Instructional Technology at North Carolina State University. Following her graduation, she worked as a Post-Doctorate Research Associate on internationalization. Later she joined the Department of Computer and Instructional Technology Education at Eskisehir Osmangazi University in 2014. Dr. Avci worked as a visiting scholar at Boston College on the project called An Emerging Model for Online Teacher Professional Development between 2015-2016. Currently she has been an Associate Professor at the department of Computer and Instructional Technology Education, Faculty of Education, Eskisehir Osmangazi University, Eskisehir, Turkey. Innovative educational technologies, development of instructional materials using technology for different fields, contribution of technology use in learning, communication and collaboration tools are among the research areas of Dr. Yurtseven-Avci.

\section{Zeynep YURTSEVEN AVCI}

Eskisehir Osmangazi University, Faculty of Education, Address: Eskisehir Osmangazi University, 26040, Eskisehir, Turkey

Phone: +90 222 2393750/1677

E-mail: zavci@ogu.edu.tr 


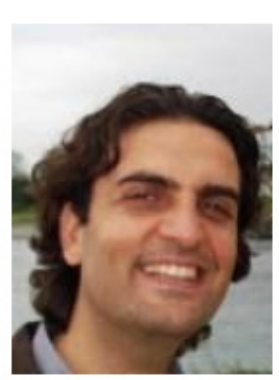

Dr. Irfan SURAL, Associate Professor, Computer and Instructional Technology Education, Faculty of Education, Eskisehir Osmangazi University, Eskisehir, Turkey. Dr. Irfan Sural has a strong practical as well as theoretical background in the use of technology for learning. His professional career has been a mixture of national and international jobs in various areas, which greatly enriched his knowledge and experience about Information Technology especially in the field of distance education. His research interest mainly focuses on personalized learning systems, building distance education infrastructures, artificial intelligence in distance education, learning management systems and deploying open source software in education.

\section{Irfan SURAL}

Eskisehir Osmangazi University, Faculty of Education,

Address: Eskisehir Osmangazi University, 26040, Eskisehir, Turkey

Phone: +90 222 2393750/1615

E-mail: isural@gmail.com

\section{REFERENCES}

Abdusselam, M. S. (2014). Teachers' and students' views on using augmented reality environments in physics education: 11 th grade magnetism topic example. Pegem JournalofEducation and Instruction, 4(1), 5974. Retrieved February 19, 2021 from http://pegem.net/dosyalar/dokuman/38291makale\%204. pdf

Abdusselam, M. S., \& Karal, H. (2012). Fizik ogretiminde artirilmis gerceklik ortamlarinin ogrenci akademik basarisi uzerine etkisi: 11. Sinif manyetizma konusu ornegi [The effect of mixed reality environments on the students' academic achievement in physics education: 11th grade magnetism topic example]. Journal of Research in Education and Teaching, 1(4), 170-181. Retrieved February 19, 2021 from http://jret.org/FileUpload/ks281142/File/20a.abdusselam.pdf

Abdusselam, M. S., Kilis, S., Sahin Cakir, C., \& Abdusselam, Z. (2018). Examining Microscopic Organisms under Augmented Reality Microscope: A 5E Learning Model Lesson. Science Activities, 55(1-2), 68-74. doi: 10.1080/00368121.2018.1517717

Ahmad, S. A., Abdullahi, I. M., \& Usman, M. (2015). General Attitude and Acceptance of Holography in Teaching among Lecturers in Nigerian Colleges of Education. IAFOR Journal of Education. https://eric.ed.gov/?id=EJ1100658

Aina, O. (2010). Application of holographic technology in education. Kemi-Tornio University of Applied Sciences. Retrieved February 19, 2021 from https://www.theseus.fi/handle/10024/23101

Aktamis, H., \& Arici, V. A. (2013). Sanal gerceklik programlarinin astronomi konularinin ogretiminde kullanilmasinin akademik basari ve kaliciliga etkisi [The effects of using virtual reality software in teaching astronomy subjects on academic achievement and retention]. Mersin University Journal of the Faculty of Education, 9(2), 58-70. Retrieved February 19, 2021 from https://dergipark.org. tr/en/pub/mersinefd/issue/17383/181566?publisher=mersin-university

Arici V. A. (2013). Fen egitiminde sanal gerceklik programlari uzerine bir calisma: "Gunes sistemi ve otesi: Uzay bilmecesi” unitesi ornegi. Yayimlanmamis yuksek lisans tezi. Adnan Menderes Universitesi, Aydin. Retrieved February 19, 2021 from http://adudspace.adu.edu.tr:8080/jspui/ handle/11607/1297

Arslan, A. \& Elibol, M. (2015). Egitsel artirilmis gerceklik uygulamalarinin incelenmesi: Android isletim sistemi ornegi. International Journal of Human Sciences, 12(2), 1792-1817. doi:10.14687/ijhs. v12i2.3524

Barkhaya, N. M. M., \& Halim, N. D. A. (2016, December). A review of application of 3D hologram in education: A meta-analysis. 2016 IEEE 8th International Conference on Engineering Education (ICEED) (pp. 257-260). Kuala Lumpur: IEEE. doi: 10.1109/ICEED.2016.7856083 
Billinghurst, M., Kato, H., \& Poupyrev, I. (2001). The magicbook-moving seamlessly between reality and virtuality. IEEE Computer Graphics and Applications, 21. doi: 6-8, 10.1109/38.920621

Caliskan, E. (2017). Examination of Turkish master theses and doctoral dissertations in terms of using innovative technologies in education among 2011-2015. Journal of Human Sciences, 14(1), 496505. doi:10.14687/jhs.v14i1.4169

Chang, G., Morreale, P. \& Medicherla, P. (2010). Applications of Augmented Reality Systems in Education. In D. Gibson \& B. Dodge (Eds.), Proceedings of SITE 2010--Society for Information Technology \& Teacher Education International Conference (pp. 1380-1385). San Diego, CA, USA: Association for the Advancement of Computing in Education (AACE). Retrieved February 19, 2021 from https://www.learntechlib.org/primary/p/33549/

Chang, K. E., Chang, C. T., Hou, H. T., Sung, Y. T., Chao, H. L., \& Lee, C. M. (2014). Development and behavioral pattern analysis of a mobile guide system with augmented reality for painting appreciation instruction in an art museum. Computers \& Education, 71, 185-197. https://www. sciencedirect.com/science/article/pii/S0360131513002868

Chang, Y. L., Hou, H. T., Pan, C. Y., Sung, Y. T., \& Chang, K. E. (2015). Apply an augmented reality in a mobile guidance to increase sense of place for heritage places. Educational Technology \& Society, 18(2), 166-178. Retrieved February 19, 2021 from https://www.jstor.org/stable/pdf/ jeductechsoci.18.2.166.pdf

Chen, C. H., Yang, J. C., Shen, S., \& Jeng, M. C. (2007). A desktop virtual reality earth motion system in astronomy education. Educational Technology \& Society, 10(3), 289-304. Retrieved February 19, 2021 from https://www.jstor.org/stable/10.2307/jeductechsoci.10.3.289

Chen, C. M., \& Tsai, Y. N. (2012). Interactive augmented reality system for enhancing library instruction in elementary schools. Computers \& Education, 59(2), 638-652. doi:10.1016/j.compedu.2012.03.001

Chen, Y. C. (2006) A study of comparing the use of augmented reality and physical models in chemistry education. In: International conference on virtual reality continuum and its applications, Hong Kong, China, pp 369-372. https://doi.org/10.1145/1128923.1128990

Craig, A. B. (2013). Understanding augmented reality: Concepts and applications. Waltham, MA: Elsevier.

Creswell, J. W. (2007). Qualitative inquiry \& research design: Choosing among five approaches. (2nd edition). Sage Publications.

Creswell, J. W. (2011). Controversies in mixed methods. In N. K. Denzin \& Y. S. Lincoln (Eds.), The SAGE handbook of qualitative research (4th ed., pp. 269-284). Sage.

Creswell, J. (2013). Qualitative inquiry and research design: Choosing among five approaches (3rd edition). USA: Sage.

Dagdalan, G. (2019). Sanal gerceklik uygulamasi destekli fen bilimleri ogretiminin ogrencilerin bilissel duzeylerine, ust bilissel farkindaliklarina ve sanal gerceklik uygulamalarina iliskin tutumlarina etkisi (The effects of viirtual reality supported science education on students' cognitive levels, meta cognitive awareness and attitudes toward virtual reality) [Unpublished master's thesis]. Ordu University.

Di-Serio, A., Ibanez, M. B., \& Kloos, C. D. (2013). Impact of an augmented reality system on students' motivation for a visual art course. Computers \& Education, 68, 586-596. https://doi.org/10.1016/j. compedu.2012.03.002

Diakidoy, I. A. N., \& Kendeou, P. (2001). Facilitating conceptual change in astronomy: A comparison of the effectiveness of two instructional approaches. Learning and Instruction, 11(1), 1-20. https:// doi.org/10.1016/S0959-4752(00)00011-6

Dunleavy, M., Dede, C., \& Mitchell, R. (2009). Affordances and limitations of immersive participatory augmented reality simulations for teaching and learning. Journal of science Education and Technology, 18(1), 7-22. https://doi.org/10.1007/s10956-008-9119-1 
Durak, A. ve Yilmaz, F. G. K. (2019). Artirilmis gercekligin egitsel uygulamalari uzerine ortaokul ogrencilerinin gorusleri. Abant Izzet Baysal Universitesi Egitim Fakultesi Dergisi, 19(2), 468-481. https://doi.org/10.17240/aibuefd.2019.19.46660-425148

Eve, E. J., Koo, S., Alshihri, A. A., Cormier, J., Kozhenikov, M., Donoff, R. B., \& Karimbux, N. Y. (2014). Performance of Dental Students Versus Prosthodontics Residents on a 3D Immersive Haptic Simulator. Journal of Dental Education, 78(4), 630-637. https://doi.org/10.1002/j.00220337.2014.78.4.tb05715.x

Farias, L., Dantas, R., \& Burlamaqui, A. (2011, September). Educ-AR: A tool for assist the creation of augmented reality content for education. In 2011 IEEE International Conference on Virtual Environments, Human-Computer Interfaces and Measurement Systems Proceedings (pp. 1-5). IEEE. doi:10.1109/VECIMS.2011.6053850

Freina, L., \& Ott, M. (2015, April). A literature review on immersive virtual reality in education: state of the art and perspectives. In the International Scientific Conference eLearning and Software for Education (Vol. 1, p. 133). "Carol I» National Defence University. https://search.proquest.com/ publication $/ 1876338$ ?accountid $=16716$

Ghuloum, H. (2010). 3D Hologram Technology in Learning Environment. Proceedings of Informing Science \& IT Education Conference (InSITE) 2010, (pp. 693-704). Retrieved February 19, 2021 from http://citeseerx.ist.psu.edu/viewdoc/download?doi=10.1.1.381.5418\&rep=rep1\&type=pdf

Gonzato, J. C., Arcila, T., \& Crespin, B. (2008). Virtual Objects on Real Oceans. 18th international conference on Computer Graphics. Moscow, Russia: GraphiCon. Retrieved February 19, 2021 from https://hal.archives-ouvertes.fr/hal-00341028

Green, J., Wyllie, A., \& Jackson, D. (2013). Virtual worlds: A new frontier for nurse education? Collegian. https://doi.org/10.1016/j.colegn.2013.11.004

Hsiao, K. F., \& Rashvand, H. F. (2011). Body language and augmented reality learning environment. MUE, 246-250, Taiwan. doi: 10.1109/MUE.2011.51

Hsiao, K. F., Chen, N. S., \& Huang, S. Y. (2011). Learning while exercising for science education in augmented reality among adolescents. Interactive Learning Environments, 20, 331-349. https:// doi.org/10.1080/10494820.2010.486682

Huang, T. C., Chen, C. C., \& Chou, Y. W. (2016). Animating eco-education: To see, feel, and discover in an augmented reality-based experiential learning environment. Computers \& Education, 96, 72-82. https://doi.org/10.1016/j.compedu.2016.02.008

Ibanez, M. B., Di-Serio, A., Villaran-Molina, D., \& Delgado-Kloos, C. (2014). Experimenting with electromagnetism using augmented reality: Impact on flow student experience and educational effectiveness. Computers \& Education, 71, 1-13. https://doi.org/10.1016/j.compedu.2013.09.004

Kageyama, A. (2013). Keynote talk 1: Simulations and visualizations of magnetic fields in nature. In System Integration (SII), 2013 IEEE/SICE International Symposium on (pp. 1-1). IEEE. doi: 10.1109/ SII.2013.6776767

Kaufmann, H., \& Schmalstieg, D. (2003). Mathematics and geometry education with collaborative augmented reality. Computers \& Graphics, 27(3), 339-345. https://doi.org/10.1145/1242073.1242086

Ke, F., \& Hsu, Y. C. (2015). Mobile augmented-reality artifact creation as a component of mobile computersupported collaborative learning. The Internet and Higher Education, 26, 3341. https://doi. org/10.1016/j.iheduc.2015.04.003

Kerawalla, L., Luckin, R., Seljeflot, S., \& Woolard, A. (2006). Making it real: Exploring the potential of augmented reality for teaching primary school science. Virtual Reality, 10, 163-174. doi: 10.1007/ s10055-006-0036-4

Kim, B. H., Jung, M. Y., \& Kim, J. (2018). Development and application of 3D-hologram maker education materials for high school students in Korea. Advanced Science Letters, 24(3), 2114-2117, doi: https://doi.org/10.1166/asl.2018.11867 
Kipper, G., \& Rampolla, J. (2012). Augmented reality: An emerging technologies guide to AR, Elsevier Science, Waltham, MA. Retrieved February 19, 2021 from http://hdl.handle.net/10045/60925

Klopfer, E., \& Squire, K. (2008). Environmental detectives: The development of an augmented reality platform for environmental simulations. Education Technology Research and Development, 56(2), 203-228, doi: https://doi.org/10.1007/s11423-007-9037-6

Koyunlu Unlu, Z. \& Dokme, I. (2020). The effect of technology-supported inquiry-based learning in science education: Action research. Journal of Education in Science, Environment and Health (JESEH), 6(2), 120-133. doi:10.21891/jeseh.632375

Lin, T. J., Duh, H. B. L., Li, N., Wang, H. Y., \& Tsai, C. C. (2013). An investigation of learners' collaborative knowledge construction performances and behavior patterns in an augmented reality simulation system. Computers \& Education, 68, 314-321. https://doi.org/10.1016/j.compedu.2013.05.011

Ling, H., \& Rui, L. (2016, August). VR glasses and leap motion trends in education, 2016 11th International Conference on Computer Science \& Education (ICCSE), Nagoya, Japan, pp. 917-920. doi: 10.1109/ ICCSE.2016.7581705

Merriam, S. (1995). What can you tell from an $\mathrm{N}$ of 1?: Issues of validity and reliability in qualitative research. PAACE Journal of Lifelong Learning, 4, 51-60. https://eric.ed.gov/?id=EJ497233

Merriam, S. B. (2009). Qualitative research: A guide to design and implementation (3rd ed). San Francisco, CA: Jossey-Bass.

Merriam, S. B. (2013). Nitel arastirma desen ve uygulama icin bir rehber. (Cev. Ed.: S. Turan). Ankara: Nobel Yayincilik.

Mills, A. J., Durepos, G., \& Wiebe, E. (2010). Sage Encyclopedia of Case Study Research (two volumes). Sage, Thousand Oaks, CA.

Morehead, M., Jones, Q., Blatt, J., Holcomb, P., Schultz, J., DeFanti, T., ... \& Spirou, G. A. (2014). Poster: BrainTrek-An immersive environment for investigating neuronal tissue. In $3 D$ User Interfaces (3DUI), 2014 IEEE Symposium on (pp. 157-158). IEEE. doi: 10.1109/3DUI.2014.6798868

Okulu, H. Z., \& Unver, A. O. (2016). Bring cosmos into the classroom: 3D hologram. Shelley, M., Kiray, A., \& Celik, I. (Ed), Education Research Highlights in Mathematics, Science and Technology (s. 81-86). ISRES Publishing. Retrieved February 19, 2021 from https://www.uebad.org/books/ ERHMST_08-05-2019.pdf\#page $=86$

Orhan, S., \& Karaman, M. K. (2011). Egitimde gerceklige yeni bir bakis: Harmanlanmis ve genisletilmis gerceklik. XVI. Turkiye'de Internet Konferansi. Retrieved February 19, 2021 from http://inet-tr.org. tr/inetconf16/bildiri/76.pdf

Ott, M., \& Tavella, M. (2009). A contribution to the understanding of what makes young students genuinely engaged in computer-based learning tasks. Procedia-Social and Behavioral Sciences, 1(1), 184-188, doi:10.1016/j.sbspro.2009.01.034

Ozarslan, Y. (2013). Genisletilmis gerceklik ile zenginlestirilmis ogrenme materyallerinin ogrenen basarisi ve memnuniyeti uzerindeki etkisi (The effect of augmented reality enhanced learning materials on learners' achievement and learners' satiifaction) [Unpublished doctoral dissertation]. Anadolu University.

Ozdemir, M. (2017). Artirilmis gerceklik teknolojisi ile ogrenmeye yonelik deneysel calismalar: Sistematik bir inceleme [Experimental studies on learning with augmented reality technology: A systematic review]. Mersin University Journal of the Faculty of Education, 13(2), 609-632. doi: 10.17860/ mersinefd. 336746

Robin, A. (2013). "Hologram as teaching agents," Journal of Physics Conf. Series 415. Retrieved February 19, 2021 from https://iopscience.iop.org/article/10.1088/1742-6596/415/1/012076/meta.

Seo, J., Kim, N., \& Kim, G. J. (2006). Designing Interactions for Augmented Reality Based Educational Contents. In: Pan Z., Aylett R., Diener H., Jin X., Gobel S., Li L. (eds) Technologies for E-Learning and Digital Entertainment. Edutainment. Lecture Notes in Computer Science, vol 3942. Springer, Berlin, Heidelberg. https://doi.org/10.1007/11736639_149. 
Stake, R. E. (2008). Qualitative case study. In N. K. Denzin \& Y. S. Lincold (Eds.), Strategies of qualitative inquiry. Sage.

Sin, A. K, \& Zaman, H. B. (2010). "Live Solar System (LSS): Evaluation of an augmented reality bookbased educational tool," 2010 International Symposium on Information Technology, Kuala Lumpur, Malaysia, pp. 1-6. doi: 10.1109/ITSIM.2010.5561320

Sommerauer, P., \& Muller, O. (2014). Augmented reality in informal learning environments: A field experiment in a mathematics exhibition. Computers \& Education, 79, 59-68, https://doi. org/10.1016/j.compedu.2014.07.013

Sudeep, U. (2013). Use of 3D hologram technology in engineering education. Journal of Mechanical and Civil Engineering, 4, 62-67. Retrieved November 13, 2020 from https:/www.researchgate.net/ publication/329208987

Tepe, T., Kaleci, D., \& Tuzun, H. (2016). Egitim Teknolojilerinde Yeni Egilimler: Sanal Gerceklik Uygulamalari. In 10th International Computer and Instructional Technologies Symposium (ICITS) (pp. 547-555). Retrieved February 19, 2021 from http://yunus.hacettepe.edu.tr/ htuzun/html/ academic/2016-ICITS\%20-TepeKaleciTuzun.pdf

Timur, B., \& Ozdemir, M. (2018). Fen egitiminde artirilmis gerceklik ortamlarinin kullanimina iliskin ogretmen gorusleri [Teachers' views on the use of augmented reality environments in science education]. International Journal of Turkish Education Sciences, 6(10), 62-75. https://dergipark. org.tr/en/pub/goputeb/issue/36631/354239.

Trundle, K. C., \& Bell, R. L. (2010). The use of a computer simulation to promote conceptual change: A quasi-experimental study. Computers \& Education, 54(4), 1078-1088. https://doi.org/10.1016/j. compedu.2009.10.012

Tsai, M. K., Liu, P. H. E., \& Yau, N. J. (2013). Using electronic maps and augmented realitybased training materials as escape guidelines for nuclear accidents: An explorative case study in Taiwan. British Journal of Educational Technology, 44(1), E18-E21. doi:10.1111/j.1467-8535.2012.01325.x

Virtual reality. (2021, Fenruary 20). In Wikipedia. https://en.wikipedia.org/wiki/Virtual_reality

Wojciechowski, R., \& Cellary, W. (2013). Evaluation of learners' attitude toward learning in ARIES augmented reality environments. Computers \& Education, 68, 570-585. https://doi.org/10.1016/j. compedu.2013.02.014

Wu, H. K., Lee, S. W. Y., Chang, H. Y., \& Liang, J. C. (2013). Current status, opportunities and challenges of augmented reality in education. Computers \& education, 62, 41-49. https://doi.org/10.1016/j. compedu.2012.10.024

Yamaguchi, T., \& Yoshikawa, H. (2012). New education system for construction of optical holography setup tangible learning with augmented reality. Journal of Physics, 415(1), 1-8. Retrieved February 19, 2021 from https://iopscience.iop.org/article/10.1088/1742-6596/415/1/012064/pdf

Yildirim, A. ve Simsek, H. (2016). Sosyal bilimlerde nitel arastirma yontemleri. Ankara: Seckin Yayincilik.

Yildirim, B., Sahin-Topalcengiz, E., Arikan, G., \& Timur, S. (2020). Using virtual reality in the classroom: Reflections of STEM teachers on the use of teaching and learning tools. Journal of Education in Science, Environment and Health (JESEH), 6(3), 231-245. doi:10.21891/jeseh.711779

Yildirim, F. S. (2020). The effect of the augmented reality applications in science class on students' cognitive and affective learning. Journal of Education in Science, Environment and Health (JESEH), 6(4), 259-267. doi:10.21891/jeseh.751023

Yildirim, G., Elban, M., \& Yildirim, S. (2018). Analysis of use of virtual reality technologies in history education: A Case Study. Asian Journal of Education and Training, 4(2), 62-69. doi: 10.20448/ journal.522.2018.42.62.69

Zagoransk, S., \& Divjak, S. (2003). Use of Augmented Reality in Education. The IEEE Region 8 EUROCON 2003 (s. 339-342). Ljubljana, Slovenia: IEEE. doi: 10.1109/EURCON.2003.1248213. 


\section{APPENDIX 1}

\section{Gunluk Yapilan Etkinlikleri Degerlendirme Formu}

Tarih Seciniz:

Adiniz Soyadiniz:

Cinsiyet:

Yas:

Kidem:

1. Bugunku egitim/etkinlikler sirasinda hangi teknolojiler hakkinda bilgi sahibi oldunuz? Aciklayiniz.

2. Bugun katildiginiz egitim/etkinlikler etkili bir sekilde duzenlenmis miydi? Aciklayiniz.

3.Sizce bu proje kisisel ve mesleki gelisiminiz icin degerli bir deneyim oldu mu? Aciklayiniz.

4. Belirtmek istediginiz diger gorusleriniz: 


\section{APPENDIX 2}

\section{Fen Egitiminde Zenginlestirilmis Materyal Uretiminde Yenilikci Yaklasimlar Egitim Oncesi Yansitma Formu}

Yonerge: Fen egitiminde zenginlestirilmis materyal uretimine yonelik egitimler duzenliyoruz. Bir fen bilimleri ogretmeni olarak, derslerinizde teknoloji kullanma durumunuz ve yenilikci teknoloji uygulamalari (artirilmis gerceklik, sanal gerceklik ve dijital hologram) hakkindaki bilgi ve deneyimlerinizi belirlemeyi amacliyoruz. Asagidaki ifadeler icin bilgi ve deneyimlerinizi bizimle paylasmanizi bekliyoruz. Lutfen, sizden elde edilen gorus ya da bilgilerin sadece bu arastirmada kullanilacagindan ve baska kimseyle paylasilmayacagindan emin olunuz. Kiymetli vaktinizi ayirarak goruslerinizi bizimle paylasmayi kabul ettiginiz icin tesekkur ederiz.

Tarih Giriniz

Adiniz Soyadiniz:

Cinsiyet:

Yas:

Kidem:

Mezun oldugunuz bolum:

\section{Genel Deneyimler}

Derslerinizde ogrencilerin dikkatini nasil topluyorsunuz?

Buz kirici etkinlikler nedir? Derslerinizde bunlardan yararlaniyor musunuz?

Derslerinizde ogretiminde zorlandiginiz konular var mi? Varsa ustesinden gelmek icin ne gibi yontemler kullaniyorsunuz?

\section{Teknoloji Deneyimleri}

Derslerinizde teknolojik materyallerden yararlaniyor musunuz?

Bir egitimci olarak egitim ve teknoloji arasindaki entegrasyonu nasil yorumlarsiniz?

Fen bilimleri dersinde kullanilabilecek ancak malzeme ve materyaller eksikliginden dolayi kullanamadiginiz hangi egitim teknolojilerinden haberdarsiniz?

Derslerinizde teknoloji kullanimina ihtiyac duyuyor musunuz? Duyuyorsaniz, genellikle dersin hangi asamasinda ve hangi konular icin?

Derslerinizde hangi teknolojik arac ve gereclerden nasil faydalaniyorsunuz?

\section{Yenilikci Teknoloji Uygulamalari Deneyimleri}

Yenilikci teknoloji uygulamalari (artirilmis gerceklik, sanal gerceklik ve dijital hologram) hakkinda bilginiz var mi?

Yenilikci teknoloji uygulamalarinda kullanilan programlar hakkinda bilgileriniz nelerdir?

Daha once derslerinizde yenilikci teknoloji uygulamalarina yer verdiniz mi? Yer verdiyseniz deneyimleriniz nelerdir?

Fen Egitiminde yenilikci teknoloji uygulamalarinin kullanilmasina iliskin dusunceleriniz nelerdir?

Yenilikci teknoloji uygulamalarinin fen egitiminde kullaniminin olumlu ve olumsuz yonleri hakkinda ne dusunuyorsunuz?

\section{Fen Egitiminde Zenginlestirilmis Materyal Uretiminde Yenilikci Yaklasimlar Egitim Sonrasi Yansitma Formu}

Yonerge: Fen egitiminde zenginlestirilmis materyal uretimine yonelik katildiginiz egitimler hakkindaki bilgi ve deneyimlerinizi belirlemeyi amacliyoruz. Asagidaki ifadeler icin bilgi ve deneyimlerinizi bizimle paylasmanizi bekliyoruz. Lutfen, sizden elde edilen gorus ya da bilgilerin sadece bu arastirmada kullanilacagindan ve baska kimseyle paylasilmayacagindan emin olunuz. Kiymetli vaktinizi ayirarak goruslerinizi bizimle paylasmayi kabul ettiginiz icin size tesekkur ederiz. 


\section{Yenilikci Teknoloji Uygulamalari Deneyimleri}

Katildiginiz yenilikci teknoloji uygulamalarina (artirilmis gerceklik, sanal gerceklik ve dijital hologram) yonelik egitimler hakkinda dusunceleriniz nelerdir?

Yenilikci teknoloji uygulamalarini derslerinizde yer vermeyi planliyor musunuz? Planliyorsaniz dersin hangi asamasinda ve hangi konu ve kavramlarin anlatiminda yer verilebilir?

Yenilikci teknoloji uygulamalarina yonelik materyal hazirlama konusunda deneyiminiz nelerdir?

Yenilikci teknoloji uygulamalarina yonelik olarak katildiginiz etkinliklerde zorlandiginiz kisimlar oldu mu? Aciklayiniz.

Yenilikci teknoloji uygulamalarinin fen egitiminde kullaniminin olumlu ve olumsuz yonleri hakkinda ne dusunuyorsunuz?

Yenilikci teknoloji uygulamalarina yonelik hazirlanan materyallerin fen egitiminde kullaniminin olumlu ve olumsuz yonleri hakkinda ne dusunuyorsunuz?

Yenilikci teknoloji uygulamalarina yonelik hazirlanan materyallerin hangi sinif duzeyi ve hangi konular icin kullanilabilecegini dusunuyorsunuz?

Yenilikci teknoloji uygulamalarina yonelik hazirlanan materyallerin fen derslerinde kullaniminin artirilmasina yonelik onerileriniz nelerdir?

Son olarak eklemek istediginiz bir sey var mi? 